\title{
Guidelines for small-scale production and purification of hepatitis $B$ surface antigen virus- like particles from recombinant Pichia pastoris
}

\author{
Maria Zahid ${ }^{1,2}$ and Ursula Rinas ${ }^{1,3}$ \\ ${ }^{1}$ Leibniz University of Hannover, Technical Chemistry - Life Science, Hannover, Germany \\ ${ }^{2}$ Lahore University of Management Sciences, Department of Biology, Lahore, Pakistan \\ ${ }^{3}$ Helmholtz Centre for Infection Research, Braunschweig, Germany \\ Running head title: Guidelines for small-scale production of HBsAg VLPs
}

\begin{abstract}
Virus-like particle (VLP)-based vaccines have been in the market since decades for preventing viral infection and have proven their usefulness also in other areas of biotechnology. Here, we describe in detail simple small-scale production and purification procedures for the generation of hepatitis B surface antigen (HBsAg) VLPs using Pichia pastoris as expression host. This protocol may also be applicable with variations to other HBsAg based VLPs additionally carrying antigens of other pathogens.
\end{abstract}

Key words

HBsAg, Pichia pastoris, Vaccine, Virus, Virus-like particle 


\section{Introduction}

Ever since the development of medical sciences, the approach of prevention being better than cure has been a driving motive to develop vaccines. Vaccines against viral diseases have been quite challenging because of the daunting nature of the viruses.

The first virus-like particle (VLP) product to be launched in the market was against Hepatitis B virus, e.g., HBsAg VLPs [1]. Since then, VLP technology has become more popular, and currently, there are two commercially available VLP-based vaccines already in the market; vaccines against Hepatitis B and human Papilloma virus infections [2]. Moreover, vaccine candidates against many emerging infections such as caused by Zika virus are based on VLP technology [3].

A universal vaccination program has led to a remarkably decreased rate of HBV infections in many countries in Asia, Africa and Europe [4]. There have been approved vaccines against HBV since 1980's and nowadays all of them are produced using recombinant DNA technology [5, 6]. Chimeric HBsAg-based VLPs are also used as scaffold to display epitopes of proteins from other infective agents such as Dengue virus [7] and the Malaria parasite [8]. VLPs offer a compact and stable protein structure which is one of the major requirements for a vaccine product. Many viral surface proteins have an in-built tendency to form VLPs under appropriate conditions [9] and then display immunogenic properties of the actual virions and hence trigger a protective immune response.

An efficient approach to produce HBsAg VLPs is based on subunit expression using yeast based expression systems such as Saccharomyces cerevisiae or Pichia pastoris [10]. The HBsAg is a very hydrophobic protein and not efficiently secreted [11]. Thus, yeast-based production leads to an intracellular maintained product [12-14]. For a long time, it was 
thought that the HBsAg VLPs are formed inside the expressing host cells. Recently, it has been shown that HBsAg VLPs do not assemble inside the cell but are formed during downstream processing $[15,16]$

Production and purification of HBsAg VLPs using $P$. pastoris has been reported many times, e.g. [15-19]. However, most published processes are only realizable in specialized laboratories. Here, we would like to offer a protocol which is practicable in non-specialized laboratories and also applicable for those not yet familiar with VLP production and purification procedures.

\section{Materials}

\subsection{Production}

i. $\quad P$. pastoris harboring gene encoding protein of interest under control the the AOX1 promoter, e.g. HBsAg [17]

ii. Yeast media components (yeast extract, peptone, yeast nitrogen base, biotin) Prepare all solutions with (double)-deionized water, $\mathrm{ddH}_{2} \mathrm{O}$ (see note 1)

iii. Shake-flasks with baffles ( $250 \mathrm{~mL}, 1 \mathrm{~L}$, if present also larger flasks)

iv. Glycerol and methanol (biological grade) as non-inducing and inducing carbon sources, respectively

v. $1 \mathrm{M}$ potassium phosphate buffer, $\mathrm{pH} 6.0$ (stock solution)

vi. Buffered medium glycerol (BMG): $100 \mathrm{mM}$ potassium phosphate, $\mathrm{pH}$ 6.0, $1.34 \%(\mathrm{w} / \mathrm{v})$ yeast nitrogen base (YNB), $4 \times 10^{-5} \%(\mathrm{w} / \mathrm{v})$ biotin, $1 \%(\mathrm{v} / \mathrm{v})$ glycerol

vii. Buffered medium methanol (BMM): $100 \mathrm{mM}$ potassium phosphate, $\mathrm{pH}$ 6.0, $1.34 \%(\mathrm{w} / \mathrm{v})$ yeast nitrogen base (YNB), $4 \times 10^{-5} \%(\mathrm{w} / \mathrm{v})$ biotin, $0.5 \%$ methanol viii. Shaking incubator preset to $30^{\circ} \mathrm{C}$ 
ix. Pipette set and tips, tubes for centrifugation and storage

$\mathrm{x}$. Centrifuges with temperature control for harvesting the culture and separating soluble and insoluble fractions

\subsection{Downstream processing}

i. $\quad$ Acid-washed glass beads (0.45 mm diameter)

ii. Tween 20 (biological grade)

iii. $\quad$ Polyethylenglycol (PEG) 6000

iv. Aerosil 380 (Evonik, Hanau, Germany)

v. FPLC system with ion exchange (DEAE Sepharose FF, 20 - 200 mL, GE healthcare) and gel filtration (Sephacryl-S300, 26/60, 320 mL, GE healthcare) columns

vi. $\quad$ FPLC buffers (for detailed recipes, see Table 1)

vii. Phosphate buffered saline (PBS): $137 \mathrm{mM} \mathrm{NaCl,} 2.7 \mathrm{mM} \mathrm{KCl}, 10 \mathrm{mM}$ $\mathrm{Na}_{2} \mathrm{HPO}_{4}, 1.76 \mathrm{mM} \mathrm{KH}_{2} \mathrm{PO}_{4}, \mathrm{pH} 7.2$

viii. Concentrators, $10 \mathrm{kDa}$ molecular weight cut-off (MWCO)

ix. Cellulose acetate dialysis membrane (14 kDa MWCO)

\subsection{Analytical methods}

i. $\quad$ UV-VIS spectrophotometer for measuring the optical density at $600 \mathrm{~nm}$ $\left(\mathrm{OD}_{600}\right)$ and cuvettes (1mm path length)

ii. $\quad$ Protein quantification reagent (Bradford, BCA etc)

iii. $\quad$ SDS-PAGE sample buffer: 10 mM Tris-HCl, pH 6.8, 1 mM EDTA, 2.5\% (w/v) SDS, $0.2 \%$ Bromophenol blue, 45\% (v/v) $\beta$-mercaptoethanol, $5 \%(\mathrm{v} / \mathrm{v})$ glycerol

iv. SDS-PAGE gels (12\%), molecular weight marker, and electrophoresis apparatus 
v. Fixing and Colloidal Coomassie Blue staining solution [20]

vi. Transfer apparatus for Western blotting

vii. Polyvinylidene difluoride (PVDF) membrane

viii. Buffers for immunoblotting

i. $\quad$ Tris buffer saline (TBS): $25 \mathrm{mM}$ Tris-HCl, $\mathrm{pH}$ 7.5, $150 \mathrm{mM} \mathrm{NaCl}$

ii. $\quad$ TBS-Tween 20 (TBS-T): TBS, pH 7.5, 0.5\% Tween 20

iii. Blocking buffer: TBS-T, pH 7.5, 2\% bovine serum albumin (or 2\% skim milk powder)

ix. Primary and horse radish peroxidase (HRP)-labbeled secondary antibodies for HBsAg

x. Tetramethylbenzidine (TMB) detection substrate ("insoluble” for immunoblotting, generating insoluble product and "soluble" for ELISA, generating soluble product), plate reader ELISA plates and 96-well ELISA plates

xi. CFormvar coated Cu-grids (300 mesh)

xii. $\quad 2 \%(w / v)$ uranylacetate, $\mathrm{pH} 4.5$

\section{Methods}

\subsection{Shake-flask cultivation for HBsAg production}

To test for HBsAg production, shake-flask cultures of $P$. pastoris harboring the HBsAg gene are grown at $30^{\circ} \mathrm{C}$ and $250 \mathrm{rpm}$, according to manufacturer's instructions (Pichia expression Kit, Catalog no. K1710-01, Invitrogen USA). As inoculum, $100 \mu \mathrm{L}$ of glycerol stock culture is introduced to $50 \mathrm{~mL}$ BMG medium and incubated for 12-16 h or until the OD600 reaches 15. Subsequently, $10 \mathrm{~mL}$ of this inoculum is introduced into $1 \mathrm{~L} \mathrm{BMG}$ medium to start the main culture(s) (see note 2), which is further incubated until OD600 $=8$. After approx. $14 \mathrm{~h}$, 
the cells are harvested and resuspended into BMM to start production. Induction is continued with regular addition of methanol i.e., 0.5\% volume after every 24 hours and HBsAg accumulation is analyzed by SDS-PAGE analysis (Fig. 1, see note 3).

\subsection{High cell density cultivation for HBsAg production using $P$. pastoris GS115}

If the laboratory is equipped to run controlled bioreactor cultivations (e.g. equipped for controlled continuous methanol feeding to keep the methanol concentration constant) detailed information on fed-batch procedures to produce HBsAg can be found elsewhere [13] (see note 4).

\subsection{Culture harvesting}

In shake flask cultures, production continues up to $120 \mathrm{~h}$ after induction. Best timing needs to be tested empirically. For harvesting the culture, use continuous-flow centrifuges (for controlled bioreactor fed-batch cultivations) or buckets of $250 \mathrm{~mL}$ to pellet the biomass at $4^{\circ} \mathrm{C}$ and 4,000 rpm (3,345 × g) for $20 \mathrm{~min}$. Time course samples and biomass for HBsAg purification can be stored at $-20^{\circ} \mathrm{C}$ for about one week and for longer periods at $-80^{\circ} \mathrm{C}$.

\subsection{Cell lysis}

To analyze for intracellular HBsAg production, glass beads ( $0.45 \mathrm{~mm}$ diameter) are an efficient and cheap option for lysis and useful for analytical and small scale purification procedures. Additionally, a homogenizer can be used for cell lysis of suspension volumes equal or larger than $10 \mathrm{~mL}$ (see note 5).

\subsubsection{Cell lysis using glass beads}

1. Wash cell pellet equivalent to a cell pellet from $1 \mathrm{ml}$ culture with an $\mathrm{OD}_{600}=100$ with 25 mM phosphate buffer (PB), pH 8.0 and resuspend in lysis buffer. 
2. Add glass beads ( $0.45 \mathrm{~mm}$ diameter) of roughly equal weight of wet cell pellet.

3. Vortex for $40 \mathrm{sec}$ at maximum speed and keep on ice for next $40 \mathrm{sec}$. Repeat the cycle of vortexing and chilling 8-10 times.

4. Centrifuge for $10 \mathrm{~min}$ at $13,000 \mathrm{rpm}(17,000 \times \mathrm{g})$ to remove cell debris and insoluble fraction of HBsAg.

5. Collect the supernatant in a fresh tube and store at $-20^{\circ} \mathrm{C}\left(-80^{\circ} \mathrm{C}\right.$ for longer periods).

\subsubsection{Cell lysis via homogenizer}

1. To perform lysis via homogenizer (e.g. Microfluidizer, Microfluidics, Newton MA, USA), resuspend $100 \mathrm{~g}$ wet biomass (obtained from 1-2 L bioreactor culture or $5 \mathrm{~L}$ shake-flask culture broth) in lysis buffer (25 mM sodium phosphate buffer, $\mathrm{pH}$ 8, 5 mM EDTA) to a final volume of $1 \mathrm{~L}(\mathrm{OD} 600 \approx 200)$.

2. Add Tween 20 to a final concentration of $0.6 \%(\mathrm{v} / \mathrm{v})$ and readjust the $\mathrm{pH}$ to $\mathrm{pH}$ 8.0.

3. Prepare the homogenizer by chilling to $4^{\circ} \mathrm{C}$, turn on the air supply and create pressure (5-8 bar).

4. Wash the homogenizer chamber with $\mathrm{ddH}_{2} \mathrm{O}$ and lysis buffer.

5. Pass cells at 12,000 psi (38 psi at inlet) through the homogenizer for $12-14$ times.

6. Proceed for the further steps of downstream processing (as shown in Fig. 2).

\subsection{Purification of HBsAg}

Lysed cells are subjected to further downstream processing mainly based on different chromatographic methods (summarized in Fig. 2).

\subsubsection{Clarification of cell lysate}

1. Perform lysis of $100 \mathrm{~g}$ wet biomass using homogenizer as described in the previous section. 
2. Slowly add solid polyethylene glycol 6000 (PEG 6000) to the cell lysate to a final concentration of $5 \%(\mathrm{w} / \mathrm{v})$ followed by the addition of $5 \mathrm{M} \mathrm{NaCl}$ to obtain a final concentration of $500 \mathrm{mM} \mathrm{NaCl}$ in about half an hour keeping everything at $4^{\circ} \mathrm{C}$.

3. Stir the mixture for $2 \mathrm{~h}$ and then let it incubate for further $12-16 \mathrm{~h}$ at $4^{\circ} \mathrm{C}$ to facilitate precipitation.

4. This suspension is clarified by centrifugation at $4^{\circ} \mathrm{C}$ and $4,000 \mathrm{rpm}(3,345 \times \mathrm{g})$ for 25 $\min$.

\subsubsection{Aerosil 380 adsorption}

1. For preparation of pre-equilibrated Aerosil, gently mix the Aerosil in $500 \mathrm{~mL}$ binding buffer (0.13 g Aerosil per $1 \mathrm{~g}$ wet biomass), centrifuge at 4,000 rpm (3,345 × g) and discard the supernatant (for recipe, see Table 1).

2. Add the PEG supernatant to the pre-equilibrated slurry of Aerosil 380 in the Aerosil binding buffer.

3. Stir the suspension obtained by mixing the PEG supernatant and the Aerosil pellet at $4^{\circ} \mathrm{C}$ and $300 \mathrm{rpm}$.

4. After 4 hours, centrifuge the Aerosil suspension at $4^{\circ} \mathrm{C}$ and $4000 \mathrm{rpm}(3,345 \times \mathrm{g})$ for $25 \mathrm{~min}$.

5. Wash the pellet twice using the $100 \mathrm{~mL}$ Aerosil washing buffer (Table 1), resuspend in $800 \mathrm{~mL}$ elution buffer (Table 1) and incubate for $12 \mathrm{~h}$ at $37^{\circ} \mathrm{C}$ and $120 \mathrm{rpm}$.

6. Separate the Aerosil eluate (supernatant fraction) from the pellet after centrifugation for $150 \mathrm{~min}$ at $25^{\circ} \mathrm{C}$ and $10,000 \mathrm{rpm}(8664.5 \times \mathrm{g})$ and further clarify by vacuumfiltration $(0.2 \mu \mathrm{m}$ pore size $)$.

7. Store the filtered eluate at $4^{\circ} \mathrm{C}$ for $24 \mathrm{~h}$ to improve stability of HBsAg, a process called aging [18]. 


\subsubsection{Ion exchange (IEX) chromatography}

1. Re-adjust the $\mathrm{pH}$ of the Aerosil eluate (approx. $800 \mathrm{~mL}$ ) to $\mathrm{pH} 8.0$ with phosphoric acid before loading on IEX column.

2. Load the Aerosil eluate (approx. $800 \mathrm{~mL}$ ) on a $200 \mathrm{~mL}$ DEAE Sepharose FF IEX column, prewashed with $1 \mathrm{M} \mathrm{NaOH}, \mathrm{ddH}_{2} \mathrm{O}$ and equilibrated with IEX binding buffer as described previously [15]. Alternatively, $20 \mathrm{~mL}$ of DEAE Sepharose FF IEX resin prewashed with $1 \mathrm{M} \mathrm{NaOH}$, ddH $\mathrm{H}_{2} \mathrm{O}$ and equilibrated with IEX binding buffer (Tables 1 and 2) can be suspended in the Aerosil eluate and subsequently used to pack a 20 $\mathrm{mL}$ column. The following purification steps are based on the utilization of a DEAE Sepharose FF self-packed $20 \mathrm{~mL}$ column (Tables 1 and 2).

3. The self-packed column is washed with IEX washing buffer (Tables 1 and 2) and the HBsAg is eluted via isocratic flow using IEX elution buffer (Tables 1 and 2).

4. The fractions containing mono- and dimeric forms of HBsAg (25 and $50 \mathrm{kDa}$, respectively) are pooled (approx. 30-40 mL eluate) (Fig. 3) and concentrated using ultrafiltration concentrator of $10 \mathrm{kDa}$ MWCO. The concentrated fractions (approx. 5 $\mathrm{mL}$ ) are further purified via gel filtration chromatography.

\subsubsection{Gel filtration (GF) chromatography and KSCN treatment}

1. For the polishing step, load the HBsAg concentrate (approx. $5 \mathrm{~mL}$ ) on preequilibrated gel filtration (GF) column (column volume $360 \mathrm{~mL}$ ) and elute with PBS, $\mathrm{pH} 7.2$ at $1 \mathrm{~mL} / \mathrm{min}$ flow rate (Tables 1 and 3). For a smaller volume of the concentrate (e.g. 1-2 mL), a GF column with a bed volume of $120 \mathrm{~mL}$ is recommended. 
2. Pool the fractions containing HBsAg (mono- and dimeric versions) (Fig. 4) and treat with KSCN, to a final molarity of $1.2 \mathrm{M}$, for partial "surface unfolding”.

3. Incubate this mixture at $100 \mathrm{rpm}$ and $37^{\circ} \mathrm{C}$ for $5 \mathrm{~h}$ in an orbital shaker.

4. Dialyze the KSCN treated HBsAg against PBS, pH 7.2 using a cellulose acetate dialysis membrane of 14 kDa MWCO. Filter-sterilize the purified HBsAg VLPs (0.2 $\mu \mathrm{m}$ pore size) and store at $4^{\circ} \mathrm{C}$.

\subsection{General analytical methods for analysis of cell growth and HBsAg concentration}

\subsubsection{Monitoring cell growth}

Cell growth is monitored by measuring the optical density at $600 \mathrm{~nm}$ wavelength via UV-vis spectrophotometer. For each sample, take an average of three readings (see note 6).

\subsubsection{SDS-PAGE analysis for (soluble) intracellular HBsAg production}

Cell samples collected during cultivation are lysed by glass beads and the soluble fraction of cell lysates corresponding to OD600 $=100$ are mixed with an equal volume of the SDS-PAGE sample buffer, vortexed for up to $1 \mathrm{~min}$ and incubated for $10 \mathrm{~min}$ at $95^{\circ} \mathrm{C} .15 \mu \mathrm{L}$ of each sample are loaded per well on a 12\% SDS-polyacrylamide gel. The gels are stained overnight with the Colloidal Coomassie Blue staining solution.

\subsubsection{Protein concentration}

Quantify the total amount of protein by bicinchoninic acid (BCA) or Bradford assay. For pure HBsAg samples, the concentration is quantified by measuring the absorbance at $280 \mathrm{~nm}$ by using $\varepsilon=3.2 \mathrm{M}^{-1} \mathrm{~cm}^{-1}$ [17] (http://web.expasy.org/protparam/). All protein samples are analyzed in triplicates. 


\subsubsection{Western blot and immunostaining}

The cell lysates are also analyzed via Western blot and immunostaining to verify the presence of HBsAg. The samples are electro-transferred from SDS-PAGE gels to an equilibrated PVDF membrane for 60 minutes. The transfer is verified by co-transfer of a prestained molecular weight marker. After blocking with blocking buffer the membrane is incubated in a solution with the primary antibody against HBsAg (e.g. linear epitope specific mouse monoclonal anti-HBsAg antibody) for $1 \mathrm{~h}$ at room temperature. After three washings steps with TBS-T the membrane is incubated for $1 \mathrm{~h}$ with horse radish peroxidase (HRP)-labelled goat-anti mouse secondary antibody and later washed twice with TBS. The immune-blot is developed using "insoluble “ TMB substrate. Once the bands are visible, the reaction is stopped by washing the membrane two to four times with $\mathrm{ddH}_{2} \mathrm{O}$. Bands corresponding to mono- and dimeric HBsAg are visible in the soluble fraction of the cell lysate (Fig. 5).

\subsubsection{ELISA analysis}

For quantification of soluble HBsAg, the samples collected during the cultivation can be analyzed by ELISA (see note 7). Soluble fractions of cell lysate samples corresponding to OD $600=100$ are diluted 100 times with PBS, pH 7.2 and $100 \mu \mathrm{L}$ of each sample and control, positive and negative, are loaded on the ELISA plate. A serial dilution of pure HBsAg VLP standard prepared in PBS is also included for the quantification. The plate is incubated at $37^{\circ} \mathrm{C}$ for $1 \mathrm{~h}$. The wells are washed with PBS and $50 \mu \mathrm{L}$ of the HRP labeled anti-HBs conjugate is added to each well and further incubated at $37^{\circ} \mathrm{C}$ for $1 \mathrm{~h}$. The wells are washed 6 times with PBS, $100 \mu \mathrm{L}$ of substrate (e.g. urea peroxide $+\mathrm{H}_{2} \mathrm{O}_{2}$ or "soluble" TMB) is added and the plate is incubated at room temperature for $30 \mathrm{~min} .100 \mu \mathrm{L}$ of $1 \mathrm{M} \mathrm{H}_{2} \mathrm{SO}_{4}$ is added to stop the reaction, the plate is scanned at $450 \mathrm{~nm}$. 


\subsubsection{Transmission electron microscopy}

The best choice to confirm and characterize the presence of HBsAg VLPs is transmission electron microscopy (TEM) (Fig. 6). Briefly, dilute the purified HBsAg VLPs with PBS, pH 7.2 to an appropriate protein concentration $(0.2-0.5 \mathrm{mg} / \mathrm{mL})$, adsorb for 1 minute to a glowdischarged CFormvar coated Cu-grids (300 mesh) and negatively stain with 2\% (w/v) uranylacetate, $\mathrm{pH}$ 4.5. Further details for TEM analysis of HBsAg VLPs are given elsewhere $[15,16]$. In addition to TEM, other useful analytical tools for VLP analysis are atomic force microscopy (AFM) and multiangle light scattering (MALS) techniques [21, 22].

\section{Notes}

1. Sterilize all media components by autoclaving at $121^{\circ} \mathrm{C}$ for $20 \mathrm{~min}$. Sensitive components, e.g. biotin, should be filter sterilized.

2. For Pichia cultures, the culture volume should not exceed $20 \%$ of the total flask volume to ensure proper aeration.

3. The parental non-producing strain $P$. pastoris GS115 should be grown as a negative control to analyze for HBsAg production. Purified HBsAg VLPs can show different migration properties on reducing SDS-PAGE gels compared to non-purified intracellular HBsAg presumably because of the presence of different non-reduced disulfide bonds. Please see also the amount of reducing agent needed for sample preparation for SDSPAGE analysis (see also Fig. 1).

4. In case there is no access to bioreactor facilities, multiple shake-flask cultures can be used to produce adequate biomass for the purification of VLPs.

5. Complete lysis should be confirmed by probing the cell lysate under a light microscope with 40x magnification. 
6. For OD measurement, collect the samples from the cultures regularly and dilute to suitable extent (between $\left.\mathrm{OD}_{600 \mathrm{~nm}} 0.1-0.8\right)$ with $0.9 \%(\mathrm{w} / \mathrm{v}) \mathrm{NaCl}$.

7. For ELISA, a commercially available HBsAg ELISA kit (Hepanostika micro ELISA, bioMérieux France) can be used. However, it is also feasible to use "in-house” ELISA strips with the appropriate specific antibodies.

Acknowledgements. We are grateful to C. Gurramkonda for critical comments.

\section{References}

1. Cregg JM, Tschopp JF, Stillman C, Siegel R, Akong M, Craig WS et al (1987) Highlevel expression and efficient assembly of hepatitis B surface antigen in the methylotrophic yeast, Pichia pastoris. Nat Biotech, 5:479-485

2. Kushnir N, Streatfield SJ, Yusibov V (2012) Virus-like particles as a highly efficient vaccine platform: diversity of targets and production systems and advances in clinical development. Vaccine, 31:58-83

3. Boigard H, Alimova A, Martin GR, Katz A, Gottlieb P, Galarza JM (2017) Zika virus-like particle (VLP) based vaccine. PLoS Negl Trop Dis, 11:e0005608

4. Meireles LC, Marinho RT, Van Damme P (2015) Three decades of hepatitis B control with vaccination. World J Hepatol, 7:2127-32

5. Roldao A, Mellado MC, Castilho LR, Carrondo MJ, Alves PM (2010) Virus-like particles in vaccine development. Expert Rev Vaccines, 9:1149-76 
6. Zhao Q, Li S, Yu H, Xia N, Modis Y (2013) Virus-like particle-based human vaccines: quality assessment based on structural and functional properties. Trends Biotechnol, 31:654-663

7. Khetarpal N, Poddar A, Nemani SK, Dhar N, Patil A, Negi P et al (2013) Denguespecific subviral nanoparticles: design, creation and characterization. J Nanobiotechnology, 11:15

8. Nardin EH, Oliveira GA, Calvo-Calle JM, Wetzel K, Maier C, Birkett AJ et al (2004) Phase I testing of a malaria vaccine composed of hepatitis B virus core particles expressing Plasmodium falciparum circumsporozoite epitopes. Infect Immun, 72:6519-27

9. Zhang L, Lua LH, Middelberg AP, Sun Y, Connors NK (2015) Biomolecular engineering of virus-like particles aided by computational chemistry methods. Chem Soc Rev, 44:8608-18

10. Kim HJ, Kim HJ (2017) Yeast as an expression system for producing virus-like particles: what factors do we need to consider? Lett Appl Microbiol, 64:111-123

11. Wampler DE, Lehman ED, Boger J, McAleer WJ, Scolnick EM (1985) Multiple chemical forms of hepatitis B surface antigen produced in yeast. Proc Natl Acad Sci USA, 82:6830-4

12. Biemans R, Thines D, Petre-Parent B, De Wilde M, Rutgers T, Cabezon T (1992) Immunoelectron microscopic detection of the hepatitis B virus major surface protein in dilated perinuclear membranes of yeast cells. DNA Cell Biol, 11:621-6

13. Gurramkonda C, Adnan A, Gabel T, Lünsdorf H, Ross A, Nemani SK et al (2009) Simple high-cell density fed-batch technique for high-level recombinant protein production with Pichia pastoris: Application to intracellular production of hepatitis B surface antigen. Microb Cell Fact, 8:13 
14. Vanz AL, Lünsdorf H, Adnan A, Nimtz M, Gurramkonda C, Khanna N et al (2012) Physiological response of Pichia pastoris GS115 to methanol-induced high level production of the hepatitis B surface antigen: catabolic adaptation, stress responses, and autophagic processes. Microb Cell Fact, 11:103

15. Gurramkonda C, Zahid M, Nemani SK, Adnan A, Gudi SK, Khanna N et al (2013) Purification of hepatitis B surface antigen virus-like particles from recombinant Pichia pastoris and in vivo analysis of their immunogenic properties. J Chromatogr B, 940:104-11

16. Zahid M, Lünsdorf H, Rinas U (2015) Assessing stability and assembly of the hepatitis B surface antigen into virus-like particles during down-stream processing. Vaccine, 33:3739-45

17. Vassileva A, Chugh DA, Swaminathan S, Khanna N (2001) Effect of copy number on the expression levels of hepatitis B surface antigen in the methylotrophic yeast Pichia pastoris. Protein Expr Purif, 21:71-80

18. Bardiya N (2006) Expression in and purification of Hepatitis B surface antigen (Sprotein) from methylotrophic yeast Pichia pastoris. Anaerobe, 12:194-203

19. Ottone S, Nguyen X, Bazin J, Berard C, Jimenez S, Letourneur O (2007) Expression of hepatitis B surface antigen major subtypes in Pichia pastoris and purification for in vitro diagnosis. Protein Expr Purif, 56:177-88

20. Candiano G, Bruschi M, Musante L, Santucci L, Ghiggeri GM, Carnemolla B et al (2004) Blue silver: a very sensitive colloidal Coomassie G-250 staining for proteome analysis. Electrophoresis, 25:1327-33

21. Kanno T, Yamada T, Iwabuki H, Tanaka H, Kuroda S, Tanizawa K et al (2002) Size distribution measurement of vesicles by atomic force microscopy. Anal Biochem, 309:196-9 
22. McEvoy M, Razinkov V, Wei Z, Casas-Finet JR, Tous GI, Schenerman MA (2011) Improved particle counting and size distribution determination of aggregated virus populations by asymmetric flow field-flow fractionation and multiangle light scattering techniques. Biotechnol Prog, 27:547-54 
Tables - Guidelines for small-scale production of HBsAg VLPs

\begin{tabular}{|c|c|c|}
\hline Step & Buffer & pH \\
\hline Lysis & $\begin{array}{l}25 \mathrm{mM} \text { PB + } 5 \mathrm{mM} \text { EDTA } \\
+0.6 \% \text { Tween } 20\end{array}$ & 8.0 \\
\hline $\begin{array}{l}\text { PEG precipitation } \\
\text { (overnight) }\end{array}$ & $\begin{array}{l}\text { lysis buffer }+500 \mathrm{mM} \mathrm{NaCl} \\
+5 \% \text { PEG } 6000\end{array}$ & 8.0 \\
\hline Aerosil binding & $25 \mathrm{mM} \mathrm{PB}+500 \mathrm{mM} \mathrm{NaCl}$ & 7.2 \\
\hline Aerosil washing & $25 \mathrm{mM}$ PB & 7.2 \\
\hline Aerosil elution & $50 \mathrm{mM} \mathrm{CBB} \mathrm{+} \mathrm{1.2} \mathrm{M} \mathrm{Urea}$ & 10.8 \\
\hline Aging & $50 \mathrm{mM}$ CBB & 10.8 \\
\hline IEX binding & $50 \mathrm{mM}$ CBB & 8.0 \\
\hline IEX washing & 50 mM Tris-HCl & 8.0 \\
\hline IEX elution & Tris-HCl + $500 \mathrm{mM} \mathrm{NaCl}$ & 8.0 \\
\hline $\begin{array}{l}\text { Concentration (e.g. } \\
\text { via Vivaspin } \\
\text { column) } \\
\end{array}$ & $\begin{array}{l}50 \mathrm{mM} \text { Tris- } \mathrm{HCl} \\
+500 \mathrm{mM} \mathrm{NaCl}\end{array}$ & 8.0 \\
\hline Gel filtration & PBS & 7.2 \\
\hline KSCN & $\mathrm{PBS}+1.2 \mathrm{M} \mathrm{KSCN}$ & 7.2 \\
\hline Dialysis & PBS & 7.2 \\
\hline
\end{tabular}

Table 1: List of buffers used during downstream processing of HBsAg VLP. IEX: ion exchange chromatography; PB: (Sodium) phosphate buffer; CBB: Sodium carbonate-bicarbonate buffer; PBS: Phosphate buffered saline.

\begin{tabular}{lll}
\hline Method step & Volume & Flow-rate \\
\hline Washing & $5 \mathrm{CV}$ & $1 \mathrm{~mL} / \mathrm{min}$ \\
\hline Elution & $5 \mathrm{CV}$ & $0.5 \mathrm{~mL} / \mathrm{min}$ \\
\hline Washing & $5 \mathrm{CV}$ & $1 \mathrm{~mL} / \mathrm{min}$ \\
\hline
\end{tabular}

Table 2: Protocol for the ion exchange chromatography (IEX) of HBsAg. CV (column volume) of self-packed column is $20 \mathrm{~mL}$. The eluate is collected in $5 \mathrm{~mL}$ fractions.

\begin{tabular}{lll}
\hline Step & Volume & Flow rate \\
\hline Equilibrium & $0.1 \mathrm{CV}$ & $1 \mathrm{~mL} / \mathrm{min}$ \\
\hline Sample application & $5 \mathrm{~mL}$ & $1 \mathrm{~mL} / \mathrm{min}$ \\
\hline Elution & $1.5 \mathrm{CV}$ & $1 \mathrm{~mL} / \mathrm{min}$ \\
\hline
\end{tabular}

Table 3: Protocol for the gel filtration chromatography of HBsAg VLPs using Sephacryl-S300, 26/60 (GE Healthcare). The total column volume (CV) is $320 \mathrm{~mL}$. The eluate is collected in $5 \mathrm{~mL}$ fractions. 
Figure and Figure captions - Guidelines for small-scale production of HBsAg VLPs

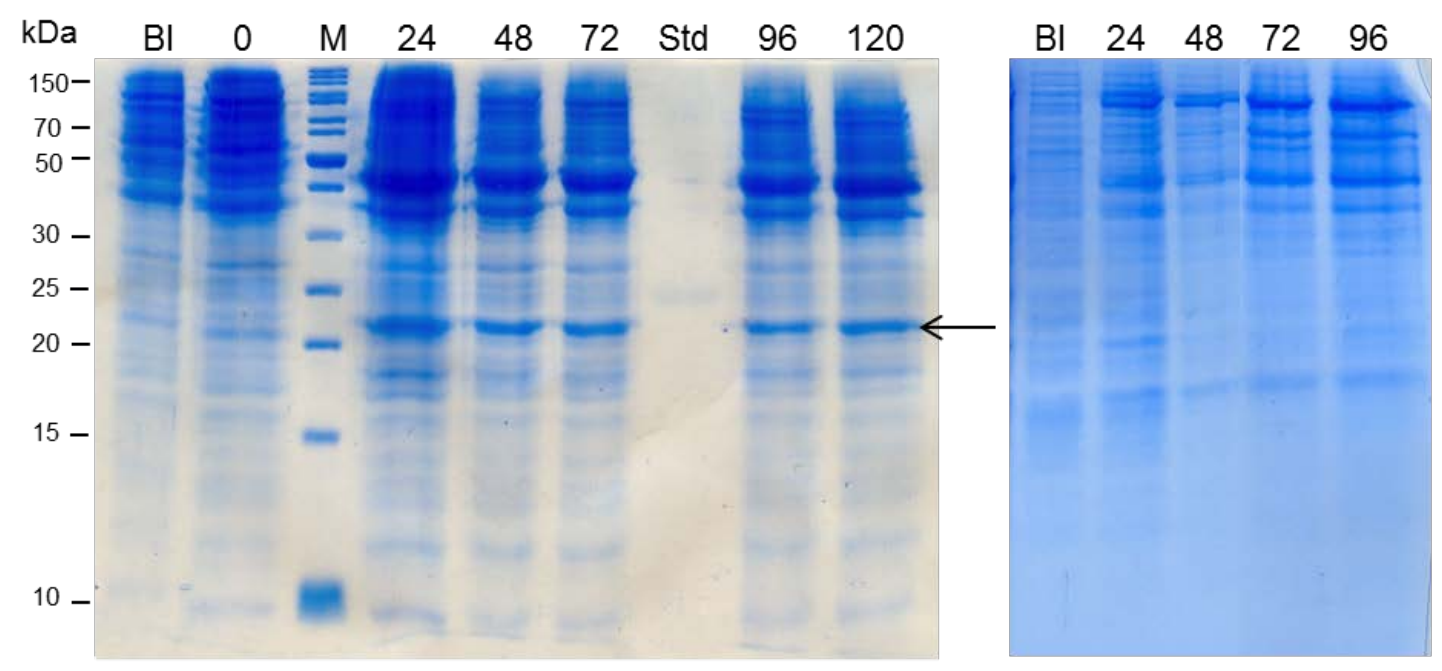

Figure 1: Production of HBsAg in shake-flask cultures. Cells were grown first in BMG and induction was started by resuspending cells in BMM containing 0.5\% methanol. Cell samples were collected 0, 24, 48, 72, 96 and 120 h post-induction, concentrated/diluted to $\mathrm{OD}_{600}=100$, and lysed via glass beads and the soluble cell fraction analyzed by SDS-PAGE. The arrow on the left gel points towards HBsAg. The gel on the right side shows samples from the non-producing parental strain GS115 grown under the same conditions as a control culture. Std, purified HBsAg VLPs at a concentration of $0.2 \mathrm{mg} / \mathrm{mL}$. BI: before induction. M: molecular weight marker. 


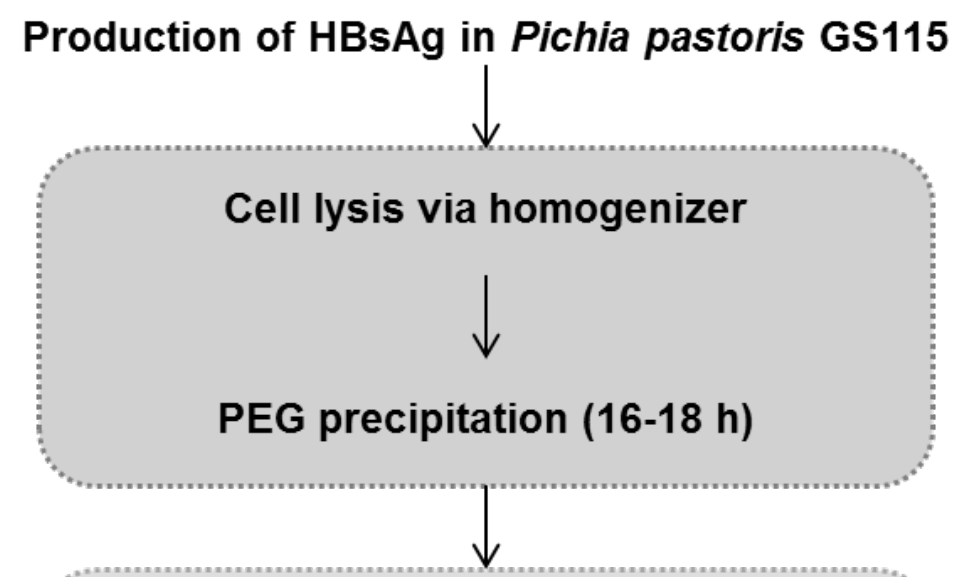

Aerosil 380 adsorption, washing and elution<smiles>C1CC1</smiles>

Ion exchange chromatography (IEX)<smiles>[CH][AlH2]</smiles>

Polishing via gel filtration (GF)<smiles>C=[V]</smiles>

$\mathrm{KSCN}$ treatment followed by dialysis<smiles>C1CC1</smiles>

Concentration, filtration and storage

Figure 2: Flow-sheet illustration of HBsAg purification. The three blocks represent three stages of purification i.e. lysis and lysate treatment, capturing of HBsAg and semi-purification and, ultimately, polishing. After salt mediated PEG precipitation, the soluble part of the cell lysate is subjected to HBsAg capturing (adsorption of HBsAg to fumed silica, Aerosil 380, through hydrophobic binding). The Aerosil eluate is processed via ion exchange (IEX) chromatography to remove further contaminants. The semi-purified product is further purified via gel filtration (GF) chromatography and treated with potassium thiocyanate (KSCN). Finally, the VLP containing solution is filtered and stored at $4^{\circ} \mathrm{C}$ until further use. 


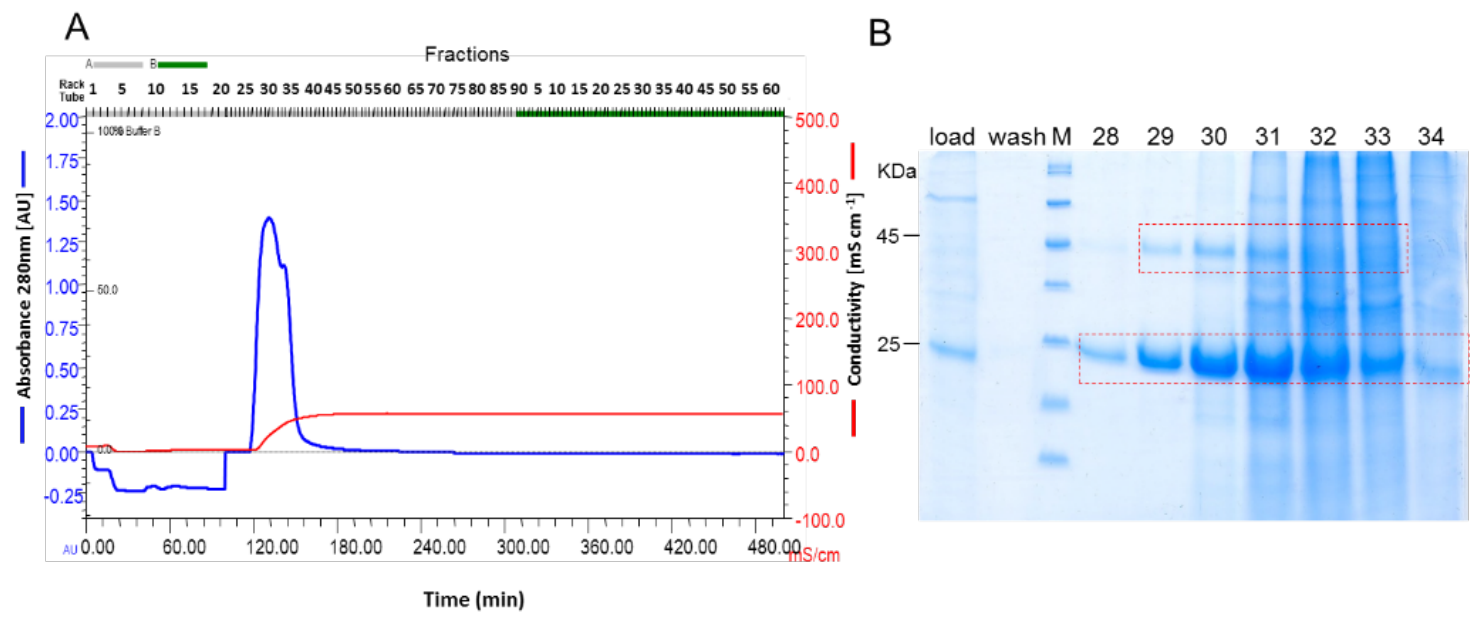

Figure 3: Ion exchange chromatography of HBsAg. (A) Chromatogram, elution step with $500 \mathrm{mM} \mathrm{NaCl}$. (B) SDS-PAGE analysis of peak fractions (numbers given on top of chromatogram and gel). The mono- and dimeric HBsAg containing fractions (marked with red rectangle) are processed for GF chromatography. 


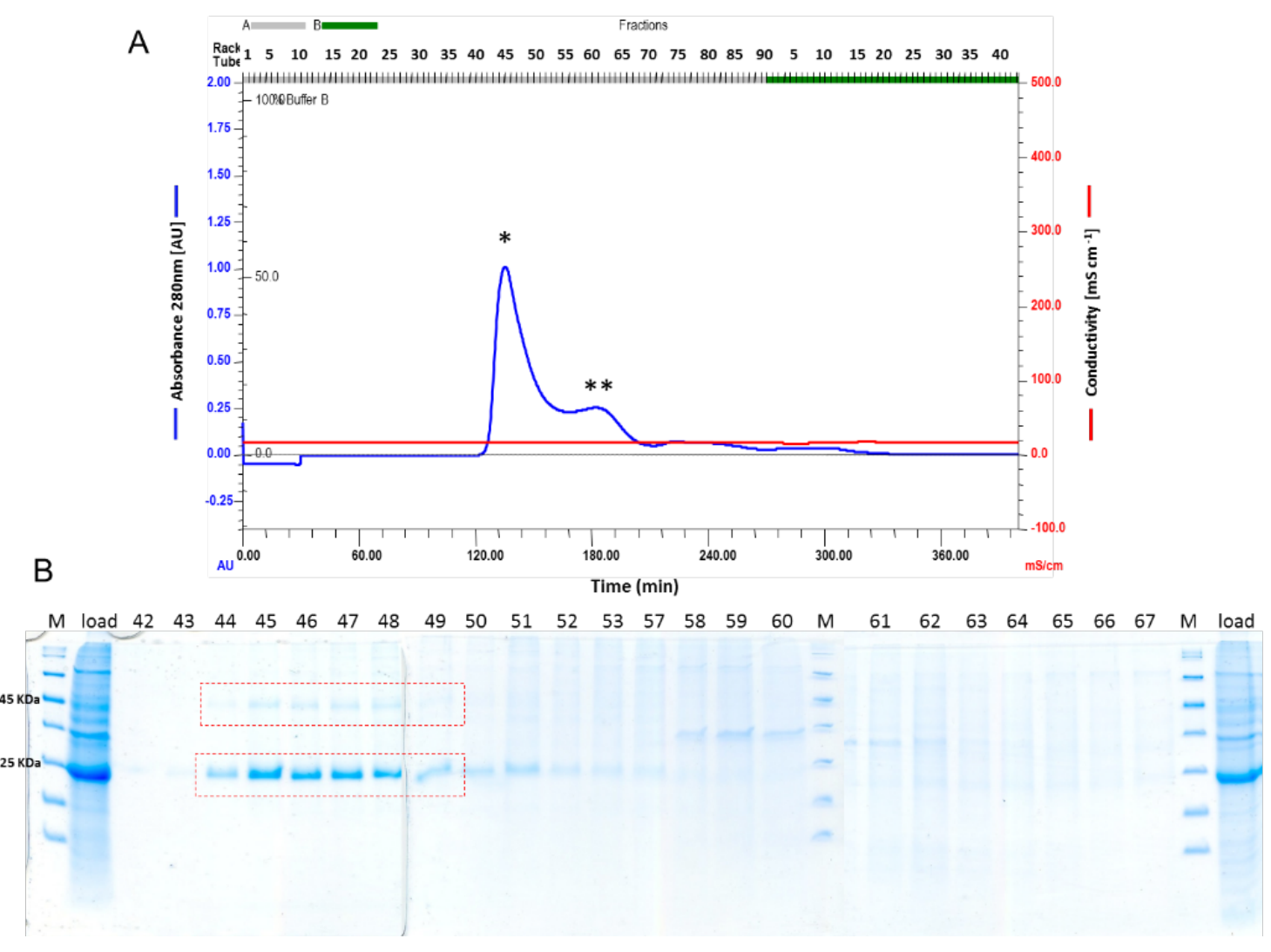

Figure 4: Polishing of HBsAg VLPs is done via gel chromatography. (A) GF chromatogram of IEX-purified, pooled and concentrated HBsAg. The two peaks of the chromatogram correspond to HBsAg VLPs $(*)$ and HBsAg not assembled into VLPs $\left({ }^{* *}\right)$. (B) SDS-PAGE analysis of GF load and peak fractions (numbers given on top of chromatogram and gel). HBsAg VLP peak fractions showing both monoand dimeric HBsAg on reducing SDS-PAGE gels (fractions marked by red rectangles are pooled and used for further processing). M: protein molecular weight marker. 


\section{A B}

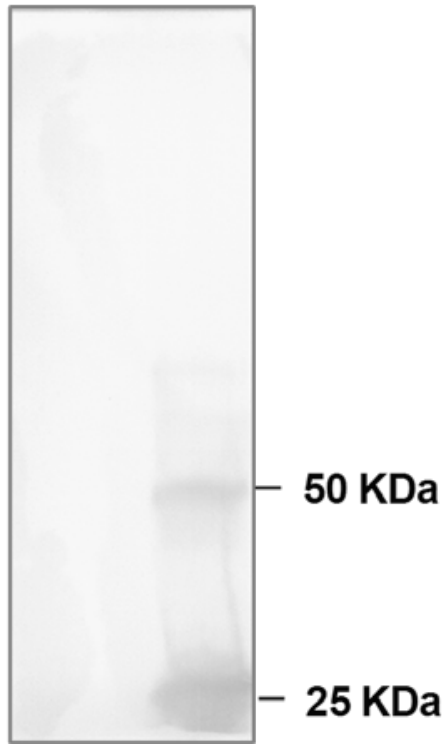

Figure 5: Immunoblot of (A) the soluble fraction of the GS115 lysate and (B) the soluble fraction of the cell lysate of HBsAg producing cells. Note the bands corresponding to mono- and dimeric HBsAg. 


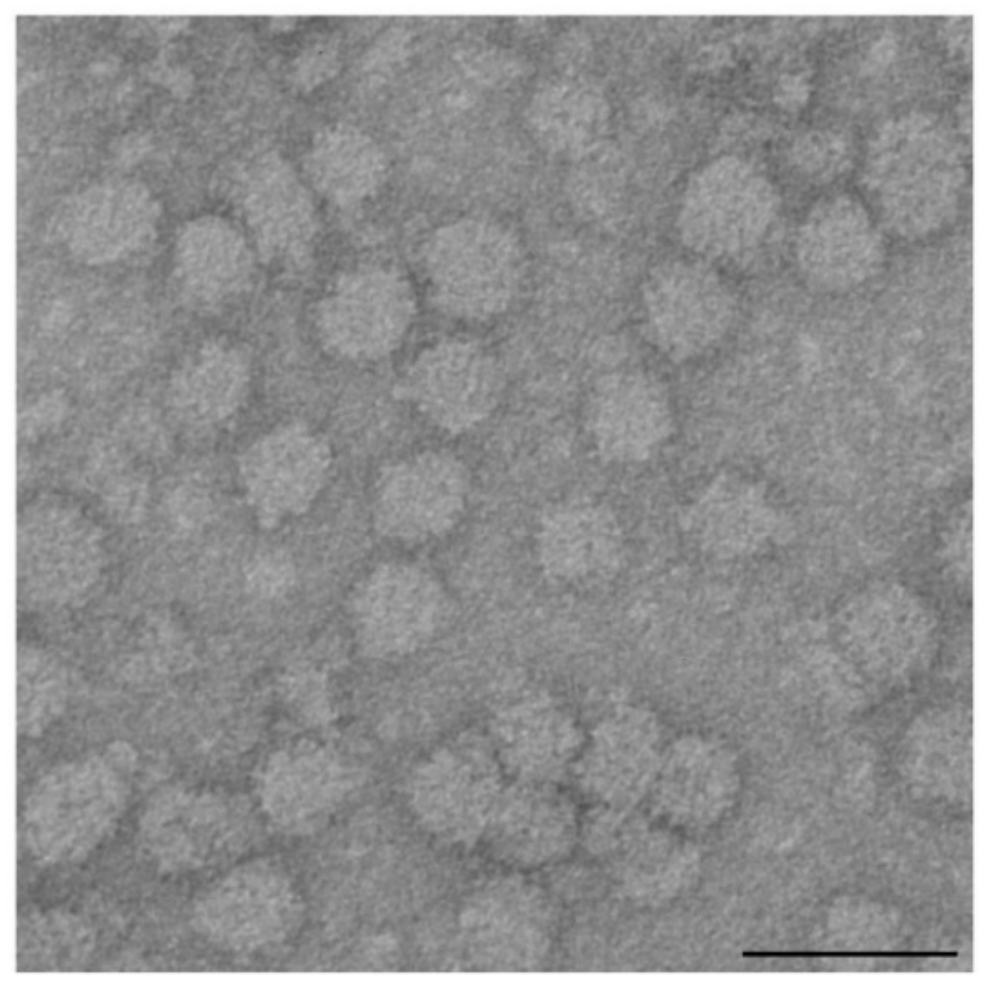

Figure 6: TEM image of purified HBsAg VLPs (HBsAg VLPs of 22-25 nm size, scale bar $=50 \mathrm{~nm}$, energy-filtered TEM Libra 120, Zeiss, Oberkochen, Germany; Photo courtesy: H. Lünsdorf). 